\title{
PEMILIHAN SAHAM YANG OPTIMAL MENGGUNAKAN CAPITAL ASSET PRICING MODEL (CAPM)
}

\author{
Dioda Ardi Wibisono ${ }^{1}$, Krisnawuri Handayani ${ }^{{ }^{*}}$ \\ ${ }^{1}$ Fakultas Ekonomi dan Bisnis, Universitas Merdeka Malang \\ *krisnawurihandayani@gmail.com
}

\begin{abstract}
:
Optimal portfolio is the basis for investors to invest in stock. Capital Asset Pricing Model (CAPM) is a method to determine the value of the risk and return of a company stock. This research used are secondary data from the closing price of the monthly stock price (monthly closing price), Stock Price Index (SPI), and the monthly SBI rate. Samples taken as many as 41 stocks in LQ45 February-July 2015 on the Indonesian Stock Exchange (ISE). The study period during 5 year from October 2010 - October 2015. The result of analysis shows that the optimal portfolio consists of 18 companie. The average return of the optimal portfolio is higher than the average risk-free return (SBI rate) and the average market return. This proves that investing in stocks is more profitable than a risk-free investment.
\end{abstract}

Keywords: Stock, CAPM, return, risk

\section{PENDAHULUAN}

Belakangan ini perekonomian di Indonesia semakin berkembang. Banyak cara yang dilakukan para investor untuk menjalankan investasi di dunia bisnis. Salah satunya dengan cara investasi saham. Pada investasi saham, seseorang investor dapat membentuk saham yang optimal dengan tingkat keuntungan tertinggi berdasarkan tingkat risiko tertentu, ataupun membentuk saham yang optimal yang berisiko paling rendah pada tingkat keuntungan tertentu. Setiap investor pasti mengharapkan saham yang optimal. Saham optimal adalah saham dengan kombinasi return ekspektasi dan risiko terbaik.

Untuk meminimalkan risiko, investor bisa melakukan diversifikasi. Diversifikasi adalah penyebaran saham dengan membeli beberapa saham yang berbeda sehingga risiko dapat dibagi-bagi. Diversifikasi ini penting karena akan mengurangi risiko tanpa harus mengurangi return yang diterima. Investor dapat melakukan diversifikasi melalui antara lain dengan membentuk portofolio yang berisi banyak aktiva, baik portofolio secara random atau diversifikasi dengan metode Markowitz.

\section{Tinjauan Pustaka \\ Investasi}

Pada dasarnya investasi secara umum berkaitan erat dengan pasar modal dan pasar uang. Investasi adalah menempatkan uang atau dana saat ini dengan harapan untuk memperoleh tambahan atau keuntungan tertentu atas uang tersebut atau dana tersebut di masa yang akan datang

Secara umum investasi dikategorikan dua jenis yaitu, Real Assets dan Financial Assets. Real Assets adalah investasi yang berwujud seperti gedung, kendaraan, tanah dan sebagainya. Sementara itu, Financial Assets merupakan dokumen (surat-surat) klaim tidak langsung pemegangannya terhadap aktiva riil pihak yang menerbitkan sekuritas tersebut. Instument yang diperdagangkan di pasar modal Indonesia 
berupa surat-surat berharga seperti saham,obligasi, dan sertifikat PT Danareksa (Ahmad, 2004). Investasi ke dalam aktiva keuangan dapat berwujud investasi langsung dan investasi tidak langsung. Investasi langsung dilakukan dengan membeli langsung aktiva keuangan dari perusahaan baik melalui perantara atau dengan cara yang lain. Sebaliknya investasi tidak langsung dilakukan dengan membeli saham dari perusahaan investasi yang mempunyai portofolio aktiva keuangan dari perusahaan lain (Rodoni, 2002). Investasi dalam aktiva keuangan ini ditunjukkan pada Gambar 1.

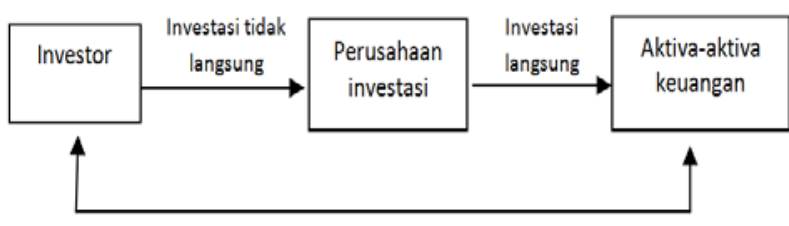

Gambar 1. Investasi Langsung dan Tidak Langsung

\section{Indeks LQ-45}

Pasar modal adalah sarana mempertemukan penjual dan pembeli dana. Tempat penawaran penjualan efek ini dilaksanakan berdasarkan satu bentuk lembaga resmi yang disebut bursa efek (Ahmad, 2004)

Pasar modal Indonesia masih dikategorikan pasar modal yang transaksinya tipis (thin market), yaitu pasar modal yang sebagian besar sekuritasnya kurang aktif diperdagangkan. IHSG yang mencakup semua saham yang tercatat (yang sebagian besar kurang aktif diperdagangkan) dianggap kurang tepat sebagai indikator kegiatan pasar modal. Oleh karena itu pada tanggal 24 Februari 1997 dikenalkan alternatif indeks lain, yaitu LQ-45. Indeks LQ-45 dimulai pada tanggal 13 juli 1994 dimana tanggal ini merupakan hari dasar indeks dengan nilai awal 100. Indeks ini dibentuk dari 45 saham yang paling aktif diperdagangkan. Beberapa pertimbangan yang mendasari pemilihan saham yang masuk di LQ-45 adalah likuiditas dan kapitalisasi pasar yang kriteria sebagai berikut: 1) Selama 12 bulan terakhir, rata-rata transaksi sahamnya masuk dalam urutan 60 terbesar di pasar reguler, 2) Selama 12 bulan terakhir, rata-rata nilai kapitalisasi pasarnya masuk dalam urutan 60 terbesar di pasar reguler, 3) Sudah tercatat di BEI paling tidak selama 3 bulan.

\section{Tingkat Pengembalian Saham Individu $\left(R_{i}\right)$}

Menurut Hartono (2013), return total adalah return keseluruhan dari suatu investasi dalam suatu periode tertentu. Return total sering disebut dengan return saja. Return total terdiri dari capital gain (loss) dan yield.

\section{Indeks Harga Saham}

Investor akan mengamati perubahan yang terjadi pada indeks harga saham untuk mengetahui perkembangannya. Indeks harga saham merupakan indikator utama yang menggambarkan pergerakan harga saham (Darmadji dkk, 2012).

Indeks harga saham terdiri dari indeks harga saham individu dan indeks harga saham gabungan. Indeks harga saham individu mencerminkan suatu rangkaian informasi historis mengenai pergerakan harga masing-masing saham, sampai tanggal tertentu (Sunaryah, 2004). Sedangkan indeks harga saham gabungan adalah pergerakan harga seluruh saham atau kelompok saham.

\section{Tingkat Pengembalian Pasar $\left(R_{m}\right)$}

Menurut Hartono (2013) Tingkat pengembalian pasar umumnya berfluktuasi searah dengan harga suatu sekuritas. Secara khusus dapat diamati bahwa kebanyakan saham cenderung mengalami kenaikan harga jika indeks harga saham naik. Sebaliknya jika indeks harga saham turun, kebanyakan saham cenderung mengalami penurunan harga. Hal ini mengisyaratkan bahwa returnreturn dari sekuritas mungkin berkorelasi karena adanya reaksi umum (common response) terhadap perubahan nilai pasar.

\section{Return Bebas Risiko ( $\left.\boldsymbol{R}_{f t}\right)$}

Aset bebas risiko merupakan aset yang tingkat returnnya di masa depan sudah bisa dipastikan saat ini, dan ditunjukkan oleh varians return sama dengan nol. 
Contoh aset bebas risiko adalah Sertifikat Bank Indonesia (SBI) yang diterbitkan oleh Bank Indonesia, dimana tidak mungkin Pemerintah atau Bank Indonesia tidak membayarkan obligasi atau SBI yang diterbitkan pada saat jatuh temponya.

\section{Risiko Investasi}

Seseorang dalam melakukan investasi cenderung menghindari risiko, tetapi tidak ada seorangpun yang terbebas dari risiko. Salah satu ukuran risiko adalah seberapa besar kemungkinan nilai portofolio dimasa depan menyimpang dari nilai yang diharapkan atau diperkirakan (Fabozzi, 2000).

Risiko total dapat dipisahkan menjadi dua bagian yaitu systematic risk dan unsistematic risk. Penggolongan total risk menjadi dua bagian yang terpisah ini dapat disebut dengan Capital Asset Pricing Model (CAPM).

\section{Systematic risk $(\boldsymbol{\beta})$}

Systematic risk atau risiko yang sistematis merupakan risiko yang tidak dapat dihindari. Risiko yang sistematis merupakan bagian dari total risk yang munculnya disebabkan oleh perubahan yang terjadi secara sistematis, dimana perubahan tersebut mempunyai pengaruh yang sama terhadap semua surat berharga. Risiko sistematis sering disebut dengan beta $(\beta)$.

Beta $(\beta)$ adalah alat pengukur volatilitas (volatility) return suatu sekuritas atau return portofolio terhadap return pasar. Beta $(\beta)$ sekuritas ke-i mengukur volatilitas return sekuritas ke-i dengan return pasar. Beta $(\beta)$ portofolio mengukur volatilitas return portofolio dengan return pasar. Oleh karena itu beta merupakan pengukur risiko sistematis (systematic risk) dari suatu sekuritas atau portofolio relative terhadap risiko pasar (Hartono, 2013).

\section{Unsystematic risk}

Unsystematic risk atau risiko yang tidak sistematis merupakan bagian dari total risk yang besarnya berbeda-beda antara satu surat berharga dengan surat berharga yang lain. Perubahan yang tidak sistematis di sini dimaksudkan adalah perubahan yang pengaruhnya tidak sama terhadap perusahaan yang satu dengan yang lain (Hartono, 2013).

\section{Capital Asset Pricing Model (CAPM)}

$$
\text { Menurut Hartono }
$$

Kemampuan untuk mengestimasi return suatu individual sekuritas merupakan hal yang penting dan diperlukan oleh investor. Untuk dapat mengestimasi return suatu sekuritas dengan baik dan mudah diperlukan suatu model estimasi. Sehingga kehadiran Capital Asset Pricing Model (CAPM) yang dapat digunakan untuk mengestimasi return suatu sekuritas dianggap penting di bidang keuangan.

CAPM merupakan sebuah teori penilaian risiko dan keuntungan aset yang didasarkan koefisien beta (indeks risiko yang tidak dapat didiversifikasi) Secara matematis CAPM dirumuskan sebagai berikut :

$$
E\left(R_{i t}\right)=R_{f t}+\beta_{i}\left(E\left(R_{m t}\right)+R_{f t}\right)
$$

Dimana :

$$
\begin{aligned}
E\left(R_{i t}\right)= & \text { tingkat return ekspektasi } \\
& \text { perusahaan i pada waktu t, } \\
R_{f t} \quad & \text { tingkat return aset bebas risiko } \\
& \text { pada waktu t, } \\
E\left(R_{m t}\right)= & \text { tingkat returnekspektasi pasar } \\
& \text { pada waktu t, } \\
\beta_{i} \quad & \text { ukuran risiko dari perusahaan i } \\
& \text { yang dapat juga mewakili } \\
& \operatorname{cov}\left(R_{i}, R_{m}\right) / \operatorname{var}\left(R_{m}\right) .
\end{aligned}
$$

\section{Penjabaran Model Capital Asset Pricing Model (CAPM)}

Sebagai contoh kasus seorang investor yang mempunyai gabungan dari dua portofolio. Dimana diasumsikan investor menginvestasikan sebagian uangnya, $\mathrm{X}$, dalam portofolio berisiko, dan sisanya (1-X), dalam portofolio tidak berisiko. Beta $(\beta)$ dari suatu portofolio adalah rata-rata tertimbang dari beta-beta sekuritas komponenkomponennya. Jadi Beta portofolio $\left(\beta_{\mathrm{p}}\right)$ adalah rata-rata tertimbang dari beta portofolio pasar dan beta dari portofolio tak 
berisiko. Beta pasar adalah 1 dan beta dari aset bebas risiko adalah 0 , sehingga :

$$
\beta_{i}=[(1-X) \times 0]+[X \times 1]=X
$$

Jadi $\beta_{\mathrm{i}}$ sama dengan presentase dari uang yang diinvestasikan dalam portofolio berisiko. Jika $100 \%$ atau kurang dana investor diinvestasikan dalam portofolio berisiko, beta portofolio akan berada diantara 0 dan 1. Jika investor meminjam dengan suku bunga bebas risiko dan menginvestasikan pinjaman tersebut dalam portofolio berisiko, sehingga $\mathrm{X}$ lebih besar dari 1 dan (1-X) negatif, beta portofolio akan lebih besar dari 1.

Expected return dari portofolio gabungan juga merupakan rata-rata tertimbang dari jumlah expected return dari dua portofolio tersebut yaitu:

$$
E\left(R_{i t}\right)=(1-X) \times R_{f t}+\beta_{i} \times E\left(R_{m t}\right)
$$

Dimana $E\left(R_{p}\right)$ dan $E\left(R_{m}\right)$ masingmasing adalah expected return dari portofolio dan expected return dari indeks pasar, dan $R_{f}$ adalah suku bunga bebas risiko. Jika diketahui bahwa $X$ sama dengan $\beta_{p}$ maka mensubstitusi $\beta_{p}$ ke dalam persamaan di atas maka diperoleh :

$E\left(R_{i t}\right)=\left(1-\beta_{i}\right) \times R_{f t}+\beta_{i} \times E\left(R_{m t}\right)$

atau

$E\left(R_{i t}\right)=R_{f}+\beta_{i}\left[E\left(R_{m t}\right)-R_{f t}\right]+e$

Persamaan di atas adalah Capital Asset Pricing Model (CAPM). Hasil teoritis ini menyatakan bahwa expected return dari suatu portofolio harus melebihi tingkat pengembalian bebas risiko dengan selisih yang proposional dengan beta portofolio (Fabozzi, 2000).

\section{Pengujian Empiris terhadap Capital Asset Pricing Model (CAPM)}

Model dari Capital Asset Pricing

Model (CAPM) adalah suatu model untuk return ekspektasi. Model ini tidak dapat diuji, karena ekspektasi adalah nilai yang belum terjadi dan belum dapat di observasi. Supaya dapat diobservasi dan dapat diuji maka digunakan nilai yang sudah terjadi atau nilai historis (ex post). Oleh karena itu, supaya model Capital Asset Pricing Model (CAPM) harus diubah menjadi model ex post sebagai berikut :

$$
R_{i t}=R_{f}+\beta_{i}\left[R_{m t}-R_{f t}\right]+e
$$

Dimana :

$R_{i t}=$ tingkat return realisasi perusahaan $\mathrm{i}$ pada waktu t,

$R_{f t}=$ tingkat return aset bebas risiko pada waktu t,

$R_{m t}=$ tingkat return realisasi pasar pada waktu t,

$\beta_{i}=$ ukuran risiko dari perusahaan i yang dapat jg mewakili $\operatorname{cov}\left(R_{i}, R_{m}\right) / \operatorname{var}\left(R_{m}\right)$.

Terlihat di model ex post ini bahwa nilai-nilai ekspektasi telah diubah menjadi nilai-nilai realisasi, yaitu $E\left(R_{i t}\right)$ dan $E\left(R_{m t}\right)$ berturut-turut menjadi $R_{i t}$ dan $R_{m t}$. Subskrip-t menunjukkan waktu terjadinya. Subskrip-t ini diperlukan karena umumnya CAPM diuji secara time-series yang melibatkan sejumlah waktu tertentu atau periode tertentu (Hartono, 2013).

\section{Garis Pasar Sekuritas (GPS)}

Dalam rangka memperoleh aset yang paling disukai, investor akan tertarik atas nilai aset yang risiko sistematisnya rendah. Sebaliknya aset yang koefisien betanya rendah cenderung akan rendah pula harga pasarnya dan relatif rendah expected returnnya. Sebaliknya aset yang tingkat risiko sistematisnya tinggi cenderung juga memberikan expected return tinggi untuk mendorong investor membeli aset tersebut (Ahmad,2004).

Garis pasar sekuritas (GPS) merupakan gambaran secara grafis dari model CAPM. GPS menggambarkan antara return ekspektasi dan risiko. 
Expected Return dan risk mempunyai hubungan yang positif. Semakin besar risiko suatu sekuritas, semakin besar return yang diharapkan. Sebaliknya semakin kecil return yang diharapkan, semakin kecil risiko yang ditanggung. Hubungan positif ini hanya berlaku untuk Expected Return, yaitu untuk return yang belum terjadi. Untuk realisasi keuntungan (yang sudah terjadi), hubungan positif ini dapat tidak terjadi. Terkadang realisasi keuntungan yang tinggi tidak selalu mempunyai risiko yang tinggi pula. Bahkan keadaan sebaliknya dapat terjadi, yaitu realisasi keuntungan yang tinggi tetapi mempunyai risiko yang kecil.

Beta $(\beta)$ untuk portofolio pasar adalah bernilai 1 . Suatu sekuritas yang mempunyai beta $(\beta)$ lebih kecil dari 1 dikatakan berisiko lebih kecil dari risiko portofolio pasar. Sebaliknya jika suatu sekuritas yang mempunyai nilai beta $(\beta)$ lebih besar dari 1 dikatakan mempunyai risiko sistematik yang lebih besar dari risiko pasar. Jika suatu sekuritas mempunyai beta ( $\beta$ ) sama dengan 1, maka diharapkan sekuritas ini mempunyai Expected Return yang sama dengan Expected Return portofolio pasar. (Hartono, 2013).

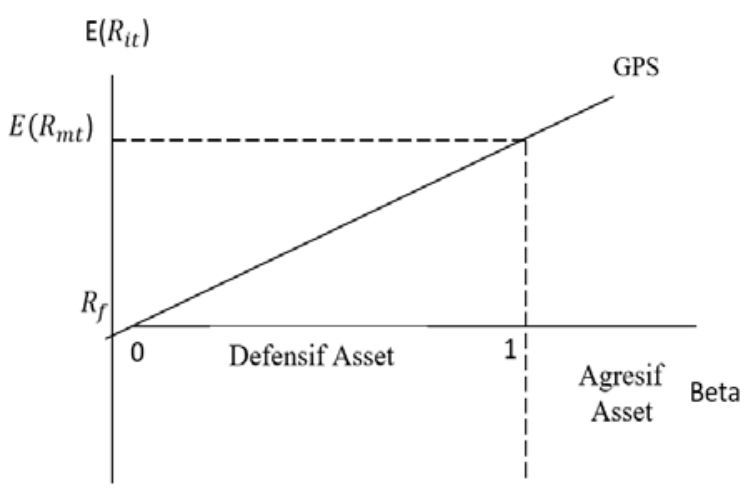

Gambar 2 Capital Asset Pricing Model (CAPM)

\section{Expected Return}

Expected Return merupakan rata-rata return saham individual. Return ekspektasi atas saham dapat diitung dengan rumus:

$$
E\left(R_{i}\right)=\frac{1}{N} \sum_{t=1}^{n} R_{i t}
$$

Dimana:

$E\left(R_{i}\right)=$ return ekspektasi saham $\mathrm{i}$;

$R_{i t}=$ return saham $i$ periode $t$

$N=$ periode pengamatan (Halim, 2003).

\section{Metode Cut Off Point (COP)}

Menurut Tam (1996): Kriteria yang diperoleh dalam penyelesaian suatu masalah tidak selalu terbatas. Oleh karena itu, untuk memilih kriteria yang layak digunakan sebagai alternatif pemilihan dalam suatu masalah dapat di tentukan derajat kebutuhannya dengan menggunakan metode COP (Cut Off Point). Untuk memperoleh penilaian yang akurat, dilakukan penilaian melalui kuisoner. Dalam penilaian kuisioner, kepentingan kriteria dibagi menjadi tiga, yaitu jika suatu elemen dinilai sangat penting (very important) maka akan diberi bobot nilai 3, cukup penting (somewhat important) diberi bobot nilai 2, dan tidak penting (not important) diberi bobot nilai 1. Seluruh kriteri yang telah diberi bobot nilai berdasarkan kuisioner diurutkan dari nilai tertinggi ke terendah. Kemudian ditentukan nilai COP dengan rumus :

$$
\begin{aligned}
& \text { Natural cut off point }=\frac{\operatorname{maks}\left(E\left(R_{i}\right)\right)+\min \left(E\left(R_{i}\right)\right)}{2} \\
& \text { Dimana: } \\
& \operatorname{maks}\left(E\left(R_{i}\right)\right)=\text { nilai rata-rata maksimum } \\
& \min \left(E\left(R_{i}\right)\right)=\text { nilai rata-rata minimum }
\end{aligned}
$$

\section{Penelitian Terdahulu}

Masrukan (2013) telah melakukan kajian berkaitan dengan pemilihan portofolio saham optimal berdasarkan MeanVar dengan data berdistribusi normal untuk mencari nilai risiko optimal pada nilai standart deviasi konstan. Wijayanti (2013) telah melakukan kajian optimalisasi portofolio dengan menggunakan Model Indeks Tunggal. Sementara itu, Yayan (2014) telah melakukan kajian tentang optimalisasi portofolio saham menggunakan DEA dan MeanVar. Berbeda dengan Masrukan (2013), 
Wijayanti (2013), dan Yayan (2014) pada penelitian ini menggunakan data yang berdistribusi normal dan juga yang tidak berdistribusi normal. Menggunakan metode Capital Asset Pricing Model (CAPM) untuk mencari tingkat keuntungan (return) dan tingkat risiko $(\beta)$ saham. CAPM merupakan model untuk mengestimasi return. Beta $(\beta)$ pada CAPM merupakan risiko yang sistematis. Sealanjutnya dilakukan pemilihan portofolio saham yang optimal dengan menggunakan metode Cut Off Point (COP).

\section{METODE}

Ruang lingkup penelitian ini adalah : 1) Menggunakan metode purposive sampling, maka sampel yang digunakan adalah 41 saham perusahaan dari 45 saham perusahaan yang tarcatat pada LQ45 periode februari-juli 2015 pada Bursa Efek Indonesia dengan kriteria sudah go public pada bulan September 2010, 2) Data return yang digunakan adalah total return bulanan (dividen dianggap diinvetasikan kembali berupa saham), 3) Data yang digunakan adalah saham bulanan saat closing price periode Oktober 2010-Oktober 2015, Indeks Harga Saham Gabungan (IHSG) periode Oktober 2010-Oktober 2015, dan Suku Bunga Sertifikat Bank Indonesia (SBI).

Penelitian ini dilaksanakan di Pojok Bursa Efek Indonesia (BEI) di Fakultas Ekonomi dan Bisnis Universitas Brawijaya.

\section{Teknik Pengumpulan Data}

Teknik pengumpulan data yang digunakan pada penelitian ini adalah teknik dokumentasi. Menurut Nasution (2003), teknik dokumen yaitu teknik yang bahan dokumenternya telah tersedia, dimana dapat memberikan latar belakang yang lebih luas mengenai pokok penelitian serta merupakan bahan utama dalam penelitian historis.

Data yang digunakan pada penelitian ini adalah adta sekunder. Data sekunder merupakan data yang diperoleh secara tidak langsung dari objek yang diteliti. Data yang digunakan dalam penelitian ini adalah sebagai
2) Indeks Harga Saham Gabungan( IHSG), dan 3) Suku Bunga SBI.

Data yang digunakan adalah data saham perusahaan-perusahaan yang teraftar di LQ45 periode Februari-Oktober 2015 pada Bursa Efek Indonesia(BEI).

\section{Teknik Analisis Data}

Dalam analisis data, langkah-langkah yang dilakukan sebagai berikut:

1. Menghitung dengan Capital Aset Pricing Model (CAPM)

a. Mengumpulkan data perusahaan yang akan digunakan berupa closing price

b. Mengumpulkan data Indeks Harga Saham Gabungan (IHSG)dansuku bunga SBI yang akan digunakan.

c. Menghitung tingkat pengembalian saham masing-masing perusahaan $\left(R_{i}\right)$ dan rata-ratanya $\left(\bar{R}_{\mathrm{n}}\right)$

d. Menghitung tingkat pengembalian pasar $\left(R_{m}\right) \quad$ dan rata-ratanya $\left(\overline{R_{m}}\right)$ menggunakan IHSG

e. Menghitung nilai $\operatorname{cov}\left(R_{i}, R_{m}\right)$ dan $\operatorname{var}\left(R_{m}\right)$

f. Menghitung risiko sistematis dari masing-masing saham individu $\left(\beta_{i}\right)$

g. Menghitung tingkat pengembalian bebas risiko $\left(R_{f}\right)$ melalui suku bunga SBI

h. Menghitung tingkat pengembalian yang diharapkan $\mathrm{E}\left(R_{i t}\right)$

2. Pemilihan dengan Cut Off Point (COP)

a. Membentuk kandidat saham yang optimal

b. Membentuk saham yang optimal dengan menggunakan metode Cut Off Point.

\section{HASIL DAN PEMBAHASAN \\ Penentuan Saham-saham Sebagai Kandidat Portofolio dengan menggunakan Capital Asset Pricing Model (CAPM)}

\section{Tingkat Pengembalian Saham Individu}

Dihitung dengan cara

membandingkan antara harga penutupan 
saham (closing price) pada bulan ke-t dikurangi dengan harga penutupan saham (closing price) pada bulan ke t-1 atau harga penutupan saham pada bulan sebelumnya, kemudian dibagi dengan harga penutupan saham pada bulan ke t-1. Harga penutupan saham-saham perusahaan yang dijadikan sebagai sampel penelitian ini dari Oktober 2010 sampai Oktober 2015.

Tingkat pengembalian saham individu dapat dihitung dengan menggunakan persamaan sebagai berikut :

$R_{i}=\frac{P_{t}-P_{t-1}}{P_{t-1}}$

Dimana :

$\begin{array}{ll}P_{t} & =\text { harga saham penutup (closing } \\ & \text { price) pada waktu } t \\ P_{t-1} & =\text { harga saham penutup (closing } \\ & \text { price) pada waktu sebelumnya } \\ & (t-1)\end{array}$

Hasil perhitungan tingkat pengembalian saham individu $\left(\mathrm{R}_{\mathrm{i}}\right)$ dari 41 saham perusahaan dapat dilihat pada Tabel 1 sebagai berikut:

Tabel 1. Tingkat Pengembalian Saham Individu $\left(\mathrm{R}_{\mathrm{i}}\right)$

\begin{tabular}{lr}
\hline \multicolumn{1}{c}{ Nama Perusahaan } & \multicolumn{1}{c}{ Ri } \\
\hline Bank Mandiri (Persero) Tbk & 0.00555026 \\
Bumi Serpong Damai Tbk & 0.015078529 \\
Ciputra Development Tbk & 0.023509166 \\
Excelcomindo Pratama Tbk & 0.002239528 \\
Global Mediacom Tbk & 0.0232942 \\
Gudang Garam Tbk & 0.00144307 \\
Indo Tambang Raya Megah & -0.01766888 \\
Tbk & \\
Indocement Tunggal Prakarsa & 0.003092983 \\
Tbk & 0.009121936 \\
Jasa Marga (Persero) Tbk & 0.018806021 \\
Lippo Karawaci Tbk & -0.0013878 \\
PP London Sumatra Indonesia & \\
Tbk & -0.01492669 \\
Tambang Batubara Bukit Asam & 0.033486383 \\
Media Nusantara Citra Tbk & 0.010452669 \\
United Tractor Tbk & -0.00096249 \\
Vale Indonesia Tbk & -0.01551774 \\
\hline Adaro Energy Tbk & \\
\hline
\end{tabular}

\begin{tabular}{lr}
\hline \multicolumn{1}{c}{ Nama Perusahaan } & \multicolumn{1}{c}{ Ri } \\
\hline AKR Corporindo Tbk & 0.028634027 \\
Astra Argo Lesatari Tbk & 0.004630834 \\
Unilever Indonesia Tbk & 0.016370316 \\
Telekomunikasi Indonesia & 0.02404035 \\
(Persero) Tbk & 0.032224328 \\
Wijaya Karya (persero) Tbk & 0.02584 \\
Adhi Karya (Persero) Tbk & 0.019519 \\
Alam Sutera Realty Tbk & -0.02176 \\
Aneka Tambang (Persero) Tbk & 0.004636 \\
Astra Internasional Tbk & 0.013625 \\
BCA (Persero) Tbk & 0.010899 \\
BNI (Persero) Tbk & 0.009138 \\
BRI (Persero) Tbk & -0.0014 \\
BTN (Persero) Tbk & 0.001156 \\
Charoen Pokphand Indonesia & \\
Tbk Indofood CBP Sukses Makmur & 0.017552 \\
Tbk & 0.006678 \\
Kalbe Farma Tbk & 0.052113 \\
Matahari Department Store Tbk & 0.026898 \\
Matahari Putra Prima Tbk & 0.002151 \\
Pakuwon Jati Tbk. & 0.036247 \\
Pembangunan Perumahan ( & 0.000226 \\
persero) Tbk & 0.000131 \\
Perusahaan Gas Negara & 0.00594 \\
PT Indofood Sukses Makmur & \\
Tbk & \\
Semen Indonesia (Persero) Tbk. & \\
Summarecon Agung Tbk. & \\
Surya Citra Media Tbk. & \\
\hline Sumber : data diolah & \\
\hline
\end{tabular}

Sumber : data diolah

Pada Tabel 1 dapat diketahui bahwa dari 1 saham terdapat 34 saham yang memiliki rata-rata tingkat pengembalian positif $\left(\mathrm{R}_{\mathrm{i}}>0\right)$ dan 7 saham yang memiliki rata-rata tingkat pengembalian negatif $\left(\mathrm{R}_{\mathrm{i}}<\right.$ $0)$. Apabila dilihat dari penelitian selama 5 tahun, Ini berarti bahwa kinerja 34 perusahaan dalam performa yang baik. Sementara itu 7 kinerja perusahaan berada pada kinerja yang kurang baik.

Saham perusahaan Matahari Department Store Tbk memiliki rata-rata tingkat pengembalian saham tertinggi daripada yang lain, yaitu sebesar 0,052113 atau 5,2113\% dan saham perusahaan Aneka Tambang (persero) Tbk memiliki rata-rata tingkat pengembalian saham terkecil yaitu sebesar $-0,02176$ atau $-2,176 \%$. Pada 
umumnya pergerakan nilai tingkat pengembalian saham $\left(\mathrm{R}_{\mathrm{i}}\right)$ masing-masing perusahaan berbeda-beda, sehingga dapat disimpulkan melalui rata-rata dari total tingkat pengembalian saham pada masingmasing perusahaan selama 5 tahun pengamatan.

\section{Tingkat Pengembalian Pasar $\left(R_{m}\right)$}

Tingkat pengembalian pasar didasarkan pada perkembangan indeks pasar. Pada pasar modal Indonesia, indeks pasar yang digunakan adalah Indeks Harga Saham Gabungan (IHSG) atau indeks saham sektoral. Pada penelitian ini menggunakan IHSG karena dalam perhitungan IHSG lebih mencerminkan kondisi pasar modal secara keseluruhan yang diperoleh dari seluruh aktivitas transaksi saham-saham perusahaan yang telah go public pada pasar modal Indonesia. Perhitungan tingkat pengembalian pasar dapat dihitung dengan persamaan sebagai berikut :

$R_{m t}=\frac{I H S G_{t}-I H S G_{t-1}}{I H S G_{t-1}}$

Dimana :

$I H S G_{t} \quad=$ Indeks Harga Saham Gabungan pada waktu $t$

$I H S G_{t-1}=$ Indeks Harga Saham Gabungan pada waktu sebelumnya (t-1)

Hasil perhitungan tingkat pengembalian pasar $\left(\mathrm{R}_{\mathrm{m}}\right)$ dapat dilihat pada tabel 2 .

Tabel 2 Hasil Perhitungan Tingkat Pengembalian Pasar $\left(\mathrm{R}_{\mathrm{m}}\right)$

\begin{tabular}{|c|c|c|c|}
\hline Th & Bln & IHSG & $\mathbf{R m}$ \\
\hline \multirow{4}{*}{$\stackrel{\circ}{\stackrel{\circ}{\circ}}$} & 9 & 3501,296 & 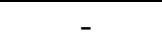 \\
\hline & 10 & 3635,324 & 0,03828 \\
\hline & 11 & 3531,211 & $-0,02864$ \\
\hline & 12 & 3703,512 & 0,048794 \\
\hline \multirow{8}{*}{$\underset{\sim}{\stackrel{-}{\circ}}$} & 1 & 3409,167 & $-0,07948$ \\
\hline & 2 & 3470,348 & 0,017946 \\
\hline & 3 & 3678,674 & 0,06003 \\
\hline & 4 & 3819,618 & 0,038314 \\
\hline & 5 & 3836,967 & 0,004542 \\
\hline & 6 & 3888,569 & 0,013449 \\
\hline & 7 & 4130,8 & 0,062293 \\
\hline & 8 & 3841,731 & $-0,06998$ \\
\hline
\end{tabular}

\begin{tabular}{|c|c|c|c|}
\hline Th & Bln & IHSG & $\mathbf{R m}$ \\
\hline & 9 & 3549,032 & $-0,07619$ \\
\hline & 10 & 3790,847 & 0,068135 \\
\hline & 11 & 3715,08 & $-0,01999$ \\
\hline & 12 & 3821,992 & 0,028778 \\
\hline \multirow{12}{*}{$\stackrel{\widetilde{D}}{\sim}$} & 1 & 3941,693 & 0,031319 \\
\hline & 2 & 3985,21 & 0,01104 \\
\hline & 3 & 4121,551 & 0,034212 \\
\hline & 4 & 4180,732 & 0,014359 \\
\hline & 5 & 3832,824 & $-0,08322$ \\
\hline & 6 & 3955,577 & 0,032027 \\
\hline & 7 & 4142,337 & 0,047214 \\
\hline & 8 & 4060,331 & $-0,0198$ \\
\hline & 9 & 4262,561 & 0,049806 \\
\hline & 10 & 4350,291 & 0,020582 \\
\hline & 11 & 4276,141 & $-0,01704$ \\
\hline & 12 & 4316,687 & 0,009482 \\
\hline \multirow{12}{*}{$\stackrel{m}{\stackrel{n}{\nu}}$} & 1 & 4453,703 & 0,031741 \\
\hline & 2 & 4795,789 & 0,076809 \\
\hline & 3 & 4940,986 & 0,030276 \\
\hline & 4 & 5034,071 & 0,018839 \\
\hline & 5 & 5068,628 & 0,006865 \\
\hline & 6 & 4818,895 & $-0,04927$ \\
\hline & 7 & 4610,377 & $-0,04327$ \\
\hline & 8 & 4195,089 & $-0,09008$ \\
\hline & 9 & 4316,176 & 0,028864 \\
\hline & 10 & 4510,631 & 0,045053 \\
\hline & 11 & 4256,436 & $-0,05635$ \\
\hline & 12 & 4274,177 & 0,004168 \\
\hline \multirow{12}{*}{$\underset{⿱ 乛}{\stackrel{\nabla}{\circ}}$} & 1 & 4418,757 & 0,033826 \\
\hline & 2 & 4620,216 & 0,045592 \\
\hline & 3 & 4768,277 & 0,032046 \\
\hline & 4 & 4840,146 & 0,015072 \\
\hline & 5 & 4893,908 & 0,011108 \\
\hline & 6 & 4878,582 & $-0,00313$ \\
\hline & 7 & 5088,802 & 0,04309 \\
\hline & 8 & 5136,863 & 0,009444 \\
\hline & 9 & 5137,579 & 0,000139 \\
\hline & 10 & 5089,547 & $-0,00935$ \\
\hline & 11 & 5149,888 & 0,011856 \\
\hline & 12 & 5226,947 & 0,014963 \\
\hline \multirow{10}{*}{$\stackrel{n}{\stackrel{n}{\sigma}}$} & 1 & 5289,404 & 0,011949 \\
\hline & 2 & 5450,294 & 0,030417 \\
\hline & 3 & 5518,675 & 0,012546 \\
\hline & 4 & 5086,425 & $-0,07832$ \\
\hline & 5 & 5216,379 & 0,025549 \\
\hline & 6 & 4910,658 & $-0,05861$ \\
\hline & 7 & 4802,529 & $-0,02202$ \\
\hline & 8 & 4509,607 & $-0,06099$ \\
\hline & 9 & 4223,908 & $-0,06335$ \\
\hline & 10 & 4605,226 & 0,090276 \\
\hline
\end{tabular}

Sumber : data diolah 
Berdasarkan Tabel 2, IHSG tahun 2011 mengalami kenaikan sebesar 12,11\% dapat dilihat dari selisih awal tahun 2011 dengan nilai 3409,167 menjadi 3821,992 pada akhir tahun 2011. Pada tahun 2012 dan IHSG mengalami peningkatan sebesar 9,51\%, tahun 2013 mengalami penurunan sebesar 4,03\%, sementara itu tahun 2014 mengalami peningkatan sebesar 16,86\%.

Rata-rata pengembalian pasar selama Oktober 2010-Oktober 2015 adalah sebesar 0,005443 atau $0,5443 \%$ dengan pembagian waktu pengamatan 61 bulan. Tingkat pengembalian pasar terbesar yaitu pada bulan Oktober 2015 sebesar 0,090276 atau 9,0276\%. Hal ini menggambarkan bahwa perdagangan sangat aktif dipasar modal. Sementara itu, tingkat pengembalian pasar terkecil yaitu pada bulan agustus 2013 sebesar -0,09008 atau $-9,008 \%$. Hal ini menggambarkan bahwa pada saat itu gejolak perdagangan di pasar modal mengalami kelesuan. Menurut sindonews.com salah satu penyebab turunnya nilai IHSG pada tahun 2013 yaitu karena Bank Sentral Amerika Serikat (The Fed) mulai merencanakan untuk mengurangi quantitative easing (QE). Bank Sentral Amerika Serikat (The Fed) menyatakan mulai mengurangi program pembelian aset bulanan sebesar USD 85 miliar.

Tingkat Pengembalian Return Bebas Risiko $\left(\boldsymbol{R}_{f}\right)$

Peningkatan pada tingkat bebes risiko yang diindikasikan oleh naiknya suku bunga Bank, akan menurunkan tingkat harga saham. Dengan kata lain, saham akan bereaksi negatif terhadap perubahan suku bunga Bank. Peristiwa ini bisa terjadi karena dengan kenaikan suku bunga, investor akan lebih memilih menanamkan modalnya pada aset keuangan yang lebih aman (bebas risiko), sekaligus memberikan tingkat pengembalian yang lebih tinggi. Sebaliknya turunnya suku bunga akan memicu pada pertumbuhan investasi dipasar modal. Tingkat Pengembalian Return Bebas Risiko $\left(\mathrm{R}_{\mathrm{f}}\right.$ ) diselesaikan menggunakan persamaan
$R_{f}=\frac{\text { tingkat suku bunga Bank Indonesia }}{12}$

Hasil perhitungan tingkat pengembalian bebas risiko dapat dilihat pada Tabel 3.

Tabel 3. Perhitungan tingkat pengembalian Bebas Risiko $\left(\mathrm{R}_{\mathrm{f}}\right)$

\begin{tabular}{|c|c|c|c|}
\hline Th & Bln & $\begin{array}{c}\text { BI rate } \\
(\%)\end{array}$ & $\mathbf{R f}$ \\
\hline \multirow{4}{*}{ 옹 } & 9 & - & - \\
\hline & 10 & 6,5 & 0,0054167 \\
\hline & 11 & 6,5 & 0,0054167 \\
\hline & 12 & 6,5 & 0,0054167 \\
\hline \multirow{12}{*}{$\vec{\nabla}$} & 1 & 6,5 & 0,0054167 \\
\hline & 2 & 6,75 & 0,005625 \\
\hline & 3 & 6,75 & 0,005625 \\
\hline & 4 & 6,75 & 0,005625 \\
\hline & 5 & 6,75 & 0,005625 \\
\hline & 6 & 6,75 & 0,005625 \\
\hline & 7 & 6,75 & 0,005625 \\
\hline & 8 & 6,75 & 0,005625 \\
\hline & 9 & 6,75 & 0,005625 \\
\hline & 10 & 6,5 & 0,0054167 \\
\hline & 11 & 6 & 0,005 \\
\hline & 12 & 6 & 0,005 \\
\hline \multirow{12}{*}{ 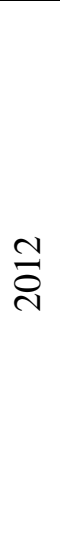 } & 1 & 6 & 0,005 \\
\hline & 2 & 5,75 & 0,0047917 \\
\hline & 3 & 5,75 & 0,0047917 \\
\hline & 4 & 5,75 & 0,0047917 \\
\hline & 5 & 5,75 & 0,0047917 \\
\hline & 6 & 5,75 & 0,0047917 \\
\hline & 7 & 5,75 & 0,0047917 \\
\hline & 8 & 5,75 & 0,0047917 \\
\hline & 9 & 5,75 & 0,0047917 \\
\hline & 10 & 5,75 & 0,0047917 \\
\hline & 11 & 5,75 & 0,0047917 \\
\hline & 12 & 5,75 & 0,0047917 \\
\hline \multirow{11}{*}{$\stackrel{m}{\circ}$} & 1 & 5,75 & 0,0047917 \\
\hline & 2 & 5,75 & 0,0047917 \\
\hline & 3 & 5,75 & 0,0047917 \\
\hline & 4 & 5,75 & 0,00479 \\
\hline & 5 & 5,75 & 0,00479 \\
\hline & 6 & 6 & 0,005 \\
\hline & 7 & 6 & 0,005 \\
\hline & 8 & 6 & 0,005 \\
\hline & 9 & 7 & 0,00583 \\
\hline & 10 & 7,25 & 0,00604 \\
\hline & 11 & 7,25 & 0,00604 \\
\hline
\end{tabular}




\begin{tabular}{|c|c|c|c|}
\hline Th & Bln & $\begin{array}{c}\text { BI rate } \\
\text { (\%) }\end{array}$ & $\mathbf{R f}$ \\
\hline & 12 & 7,5 & 0,00625 \\
\hline \multirow{12}{*}{$\stackrel{\nabla}{\stackrel{D}{*}}$} & 1 & 7,5 & 0,00625 \\
\hline & 2 & 7,5 & 0,00625 \\
\hline & 3 & 7,5 & 0,00625 \\
\hline & 4 & 7,5 & 0,00625 \\
\hline & 5 & 7,5 & 0,00625 \\
\hline & 6 & 7,5 & 0,00625 \\
\hline & 7 & 7,5 & 0,00625 \\
\hline & 8 & 7,5 & 0,00625 \\
\hline & 9 & 7,5 & 0,00625 \\
\hline & 10 & 7,5 & 0,00625 \\
\hline & 11 & 7,625 & 0,00635 \\
\hline & 12 & 7,75 & 0,00645 \\
\hline \multirow{10}{*}{$\stackrel{\text { 뭉 }}{\stackrel{2}{N}}$} & 1 & 7,75 & 0,00645 \\
\hline & 2 & 7,5 & 0,00625 \\
\hline & 3 & 7,5 & 0,00625 \\
\hline & 4 & 7,5 & 0,00625 \\
\hline & 5 & 7,5 & 0,00625 \\
\hline & 6 & 7,5 & 0,00625 \\
\hline & 7 & 7,5 & 0,00625 \\
\hline & 8 & 7,5 & 0,00625 \\
\hline & 9 & 7,5 & 0,00625 \\
\hline & 10 & 7,5 & 0,00625 \\
\hline
\end{tabular}

Sumber : data diolah

Berdasarkan Tabel 3 rata-rata tingkat suku bunga Bank Indonesia pada Oktober 2010 - Oktober 2015 adalah sebesar 0.005589 atau 0,5589 \%. Tingkat suku bunga Bank Indonesia terendah terjadi pada februari 2012-mei 2013 yaitu sebesar 5,75\%. Ini membuktikan bahwa perekonomian di Indonesia pada keadaan stabil. Sementara itu, tingkat suku bunga bank indonesia pada bulan Desember 2014 dan Januari 2015 berada di tingkat tertinggi, yaitu 7,75\%. Hal ini dikarenakan, kebijakan pemerintah mengumumkan kenaikan BBM bersubsidi dan laju inflasi yang melewati prediksi pemerintah.

Bank Indonesia dalam memutuskan mengenai naik atau turunnya tingkat suku bunga SBI berdasarkan pada faktor-faktor dalam perekonomian, antara lain : inflasi, banyaknya uang yg beredar di masyarakat, pertumbuhan ekonomi dan masalah perekonomian global. Para investor tentunya akan menginvestasikan dana mereka pada pasar modal apabila bunga yang diberikan oleh pasar modal lebih besar dari tingkat suku bungan SBI, sebaliknya investor akan menginvestasikan dana mereka miliki pada tingkat suku bunga SBI apabila bunga yang ditawarkan di pasar modal lebih rendah dari pada bunga yang ditawarkan oleh Bank Indonesia.

\section{Risiko Sistematis ( $\beta$ ) Masing-masing Saham Individu}

Salah satu ukuran risiko adalah seberapa besar kemungkinan nilai portofolio dimasa depan menyimpang dari nilai yang diharapkan atau diramalkan. Menurut teori Capital Asset Pricing Model (CAPM), semakin tinggi nilai $\beta$ maka semakin tinggi pula tingkat pengembalian yang diharapkan. Akan tetapi, teori tersebut kadang tidak berlaku pada investasi saham sesungguhnya. Karena masih banyak faktor lain yang mempengaruhi tingkat pengembalian yang diharapkan, diantaranya yaitu ukuran perusahaan, yield, leverage, arus kas, historis pertumbuhan penjualan, volume transaksi saham, struktur industry. Faktor-faktor lain tersebut terdapat pada rumus Capital Asset Pricing Model (CAPM) sebagai error (e). Risiko sistematis $(\beta)$ dapat diselesaikan dengan menggunakan persamaan

$$
\beta=\frac{\sum_{t=1}^{n}\left(R_{i}-\overline{R_{l}}\right) \cdot\left(R_{m t}-\overline{R_{m}}\right)}{\sum_{t=1}^{n}\left(R_{m t}-\overline{R_{m}}\right)^{2}}
$$

Dimana:

$R_{\tilde{i}} \quad=$ return realisasi individu

$\overline{R_{a}} \quad=$ rata-rata return realisasi individu

$R_{m t} \quad=$ return pasar pada waktu $t$

$\overline{R_{m}} \quad=$ rata-rata return pasar

Hasil tingkat risiko sistematis dapat dilihat pada Tabel 4 .

Tabel 4. Tingkat Risiko Sistematis ( $\beta$ )

\begin{tabular}{lc}
\hline \multicolumn{1}{c}{ Nama Perusahaan } & B \\
\hline Bank Mandiri (Persero) Tbk & 1.476468501 \\
Bumi Serpong Damai Tbk & 1.701329447 \\
Ciputra Development Tbk & 2.008538631 \\
Excelcomindo Pratama Tbk & 0.236623062 \\
\hline
\end{tabular}




\begin{tabular}{|c|c|}
\hline Nama Perusahaan & $\mathbf{B}$ \\
\hline Global Mediacom Tbk & 1.080889486 \\
\hline Gudang Garam Tbk & 0.555310425 \\
\hline $\begin{array}{l}\text { Indo Tambang Raya Megah } \\
\text { Tbk }\end{array}$ & $0.6410147 \mathrm{c}$ \\
\hline $\begin{array}{l}\text { Indocement Tunggal Prakarsa } \\
\text { Tbk }\end{array}$ & $1.02492140 €$ \\
\hline Jasa Marga (Persero) Tbk & 0.856337098 \\
\hline Lippo Karawaci Tbk & 1.337836273 \\
\hline $\begin{array}{l}\text { PP London Sumatra Indonesia } \\
\text { Tbk }\end{array}$ & $1.98140294 \mathrm{C}$ \\
\hline $\begin{array}{l}\text { Tambang Batubara Bukit Asam } \\
\text { (persero) Tbk }\end{array}$ & 0.961242755 \\
\hline Media Nusantara Citra Tbk & 1.4422972 \\
\hline United Tractor Tbk & 1.330236687 \\
\hline Vale Indonesia Tbk & 1.064893617 \\
\hline Adaro Energy Tbk & $0.6756456 €$ \\
\hline AKR Corporindo Tbk & 1.516540898 \\
\hline Astra Argo Lesatari Tbk & 0.64780931 \\
\hline Unilever Indone & 0.271419568 \\
\hline $\begin{array}{l}\text { Telekomunikasi Indonesia } \\
\text { (Persero) Tbk }\end{array}$ & $0.93529 \mathrm{c}$ \\
\hline Wijaya Karya (persero) Tbk & $1.73903661 \mathrm{c}$ \\
\hline Adhi Karya (Persero) Tbk & 1.713232939 \\
\hline Alam Sutera Realty Tbk & $2.02922666 \epsilon$ \\
\hline Aneka Tambang (Persero) Tbk & 1.047211118 \\
\hline Astra Internasional Tbk & 1.284982997 \\
\hline BCA (Persero) Tbk & 1.095369145 \\
\hline BNI (Persero) Tbk & 1.668412362 \\
\hline BRI (Persero) Tbk & $2.06298311 \mathrm{~S}$ \\
\hline BTN (Persero) Tbk & 1.566070517 \\
\hline $\begin{array}{l}\text { Charoen Pokphand Indonesia } \\
\text { Tbk }\end{array}$ & 884741 \\
\hline $\begin{array}{l}\text { Indofood CBP Sukses Makmur } \\
\text { Tbk }\end{array}$ & $1.71189221 \mathrm{c}$ \\
\hline Kalbe Farma Tbk & $0.71362661 \mathrm{c}$ \\
\hline Matahari Department Store Tbk & 1.013348195 \\
\hline Matahari Putra Prima Tbk & $1.44739751 \mathrm{c}$ \\
\hline Pakuwon Jati Tbk. & 1.446245195 \\
\hline $\begin{array}{l}\text { Pembangunan Perumahan ( } \\
\text { persero) Tbk }\end{array}$ & $1.98140294 \mathrm{C}$ \\
\hline $\begin{array}{l}\text { Perusahaan Gas Negara } \\
\text { (Persero) Tbk }\end{array}$ & 1.067109137 \\
\hline $\begin{array}{l}\text { PT Indofood Sukses Makmur } \\
\text { Tbk }\end{array}$ & 2.575168 \\
\hline Semen Indonesia (Persero) Tbk. & 1.529506325 \\
\hline Summarecon Agung Tbk. & 2.540001286 \\
\hline Surya Citra Media Tbk. & 0.662849266 \\
\hline
\end{tabular}

Sumber : data diolah

Berdasarkan Tabel 4 diketahui bahwa jumlah $\beta$ dari 41 saham perusahaan adalah 54,2260137. Rata-rata $\beta$ dihitung dengan cara membagi jumlah $\beta$ dengan jumlah sampel penelitian, sehingga rata-rata $\beta$ dari 41 saham perusahaan adalah 1,3225857. Dari 41 perusahaan, terdapat 11 saham perusahaan dengan $\beta<1$. Ini berarti 11 saham perusahaan tersebut mempunyai risiko lebih kecil dari pada risiko pasar. Sementara itu, terdapat 30 saham perusahaan dengan $\beta>1$. Ini berarti 30 saham perusahaan tersebut mempunyai risiko lebih besar dari pada risiko pasar. Misalnya saham perusahaan Gudang Garam Tbk mempunyai $\beta$ 0,555. Sementara itu, saham perusahaan Excelcomindo Pratama Tbk mempunyai $\beta$ 0,2366.

Besar kecilnya risiko saham perusahaan yang diukur dengan $\beta$, akan mempengaruhi besar kecilnya tingkat pengembalian yang diharapkan investor. Berdasarkan $\beta$ pada kedua saham perusahaan, maka pengembalian keuntungan yang diharapkan pada perusahaan Gudang Garam Tbk lebih tinggi daripada perusahaan Excelcomindo Pratama Tbk.

\section{Tingkat Pengembalian yang Diharapkan}

Tingkat pengembalian yang diharapkan adalah keuntungan yang diinginkan oleh investor atas investasi yang dilakukan berdasar pada preferensi risiko $(\beta)$. Beberapa asumsi digunakan untuk menyederhanakan persoalan-persoalan yang sesungguhnya terjadi di dunia nyata. Asumsi tersebut diperlukan supaya suatu model lebih mudah untuk dipahami dan untuk diuji. Hasil dari pelepasan asumsi-asumsi ternyata tidak banyak merubah hasil prediksi dari CAPM (Elton dan Gruber, 1995). Beberapa asumsi yang digunakan di model CAPM adalah :

1. Semua investor memiliki cakrawala waktu satu periode yang sama.

2. Semua investor melakukan pengambilan keputusan investasi berdasarkan pertimbangan antara nilai expected return dan deviasi standart dari portofolionya.

3. Semua investor memiliki harapan yang seragam (homogeneous expectation) terhadap faktor-faktor input yang digunakan untuk keputusan portofolio. 
Asumsi ini mempunyai implikasi bahwa dengan harga-harga sekuritas dan tingkat bunga bebas risiko yang tertentu dan dengan menggunakan input-input portofolio yang sama, maka setiap investor akan menghasilkan efficient frontiner yang sama .

4. Semua investor dapat meminjamkan sejumlah dananya (lending) atau meminjam (borrowing) sejumlah dana dengan jumlah yang tidak terbatas pada tingkat suku bunga bebas risiko.

5. Penjualan pendek (short sale) diperbolehkan.

6. Semua aktiva dapat dipecah menjadi bagian yang lebih kecil dengan tidak terbatas.

7. Semua aktiva dapat dipasarkan secara likuid sempurna.

8. Tidak ada biaya transaksi.

9. Tidak terjadi inflasi.

10. Tidak ada pajak pendapatan pribadi.

11. Investor adalah penerima harga (pricetakers).

12. Pasar modal dalam kondisi ekuilibrium.

Secara umum tingkat pengembalian yang diharapkan berbanding lurus dengan risiko yang diterima. Akan tetapi, pada kenyataannya terdapat beberapa faktor yang mempengaruhi tingkat pengembalian yang diharapkan sehingga terkadang tidak berbanding lurus dengan risiko $(\beta)$. Model CAPM tingkat pengembalian yang diharapkan ini dapat dihitung dengan persamaan sebagai berikut :

$R_{i t}=R_{f}+\beta_{i}\left[R_{m t}-R_{f t}\right]+e$

Dimana :

$R_{i t} \quad=$ tingkat return realisasiperusahaan $\mathrm{i}$ pada waktu t,

$R_{f t} \quad=$ tingkat return aset bebas risiko pada waktu t,

$R_{m t} \quad=$ tingkat returnrealisasi pasar pada waktu t,

$\beta_{i}=$ ukuran risiko dari perusahaan $\mathrm{i}$ yang dapat juga mewakili $\operatorname{cov}\left(R_{i j} R_{m}\right) / \operatorname{var}\left(R_{m}\right)$.
Kemudian dicari Expected Return dengan menggunakan persamaan

$E\left(R_{i}\right)=\frac{1}{N} \sum_{t=1}^{n} R_{i t}$

Dimana:

$E\left(R_{i}\right)=$ return ekspektasi saham i;

$R_{i t}=$ return saham $i$ periode $t$;

$N=$ periode pengamatan

Hasil perhitungan dapat dilihat pada tabel 5.

Tabel 5 Nilai Tingkat Pengembalian yang Diharapkan $\left(\mathrm{E}\left(\mathrm{R}_{\mathrm{it}}\right)\right)$.

\begin{tabular}{|c|c|}
\hline Nama Perusahaan & $\mathbf{E}\left(\mathbf{R}_{\mathrm{it}}\right)$ \\
\hline Bank Mandiri (Persero) Tbk & 0.00451077 \\
\hline Bumi Serpong Damai Tbk & 0.00321503 \\
\hline Ciputra Development Tbk & 0.00538403 \\
\hline Excelcomindo Pratama Tbk & 0.00231726 \\
\hline Global Mediacom Tbk & 0.00750728 \\
\hline Gudang Garam Tbk & 0.00817523 \\
\hline $\begin{array}{l}\text { Indo Tambang Raya Megah } \\
\text { Tbk }\end{array}$ & 0.004267903 \\
\hline $\begin{array}{l}\text { Indocement Tunggal Prakarsa } \\
\text { Tbk }\end{array}$ & 0.004391 \\
\hline Jasa Marga (Persero) Tbk & 0.00501555 \\
\hline Lippo Karawaci Tbk & 0.00753358 \\
\hline $\begin{array}{l}\text { PP London Sumatra Indonesia } \\
\text { Tbk }\end{array}$ & 0.00470967 \\
\hline $\begin{array}{l}\text { Tambang Batubara Bukit Asam } \\
\text { (persero) Tbk }\end{array}$ & 0.00276156 \\
\hline Media Nusantara Citra Tbk & 0.0061953 \\
\hline United Tractor Tbk & 0.00573344 \\
\hline Vale Indonesia Tbk & 0.00516506 \\
\hline Adaro Energy Tbk & 0.003574 \\
\hline AKR Corporindo Tbk & 0.00436 \\
\hline Astra Argo Lesatari Tbk & 0.00781118 \\
\hline Unilever Indonesia Tbk & 0.00519995 \\
\hline $\begin{array}{l}\text { Telekomunikasi Indonesia } \\
\text { (Persero) Tbk }\end{array}$ & 0.005434 \\
\hline Wijaya Karya (persero) Tbk & 0.0053098 \\
\hline Adhi Karya (Persero) Tbk & 0.007372 \\
\hline Alam Sutera Realty Tbk & 0.004611 \\
\hline Aneka Tambang (Persero) Tbk & 0.004846 \\
\hline Astra Internasional Tbk & 0.005472 \\
\hline BCA (Persero) Tbk & 0.005305 \\
\hline BNI (Persero) Tbk & 0.003557 \\
\hline BRI (Persero) Tbk & 0.004009 \\
\hline BTN (Persero) Tbk & 0.004543 \\
\hline $\begin{array}{l}\text { Charoen Pokphand Indonesia } \\
\text { Tbk }\end{array}$ & 0.006335 \\
\hline
\end{tabular}




\begin{tabular}{lr}
\hline \multicolumn{1}{c}{ Nama Perusahaan } & \multicolumn{1}{c}{$\mathbf{E}_{\left(\mathbf{R}_{\text {it }}\right)}$} \\
\hline Indofood CBP Sukses Makmur & 0.007305 \\
Tbk & 0.00561178 \\
Kalbe Farma Tbk & 0.004241 \\
Matahari Department Store Tbk & 0.0054426 \\
Matahari Putra Prima Tbk & 0.00575046 \\
Pakuwon Jati Tbk. & 0.00582172 \\
Pembangunan Perumahan & \\
(persero) Tbk & \\
Perusahaan Gas Negara & 0.00452751 \\
(Persero) Tbk & \\
PT Indofood Sukses Makmur & 0.005207 \\
Tbk Semen Indonesia (Persero) Tbk. & 0.00693133 \\
Summarecon Agung Tbk. & 0.00365996 \\
Surya Citra Media Tbk. & 0.00403439 \\
\hline
\end{tabular}

Sumber : data diolah

Pada Tabel 5 dapat diketahui bahwa semua saham memiliki expected return yang positif. Sehingga semua saham layak untuk dijadikan alternatif untuk berinvestasi. Karena saham perushaan pada LQ45 merupakan saham perusahaan yang paling diminati oleh investor.

Saham yang memiliki expected return terbesar adalah PT Gudang Garam Tbk sebesar 0.008175229 atau 0,8175299\% dengan risiko sebesar 0.555 , sementara itu saham dengan expected return terendah adalah PT Excelcomindo Pratama Tbk sebesar 0.002317264 atau $0,2317264 \%$ dengan risiko sebesar 0.2366. Ini berarti sudah membuktikan teori Capital Asset Pricing Model (CAPM). Semakin tinggi tingkat pengembalian yang diharapkan, maka semakin tinggi pula risiko yang akan dihadapi. Begitu juga sebaliknya, semakin rendah tingkat pengembalian yang diharapkan, maka semakin rendah pula risiko yang akan dihadapi. Akan tetapi, teori Capital Asset Pricing Model (CAPM) tidak selalu benar, karena masih ada faktor lain yang mempengaruhi seperti ukuran perusahaan, yield, leverage, arus kas, historis pertumbuhan penjualan, volume transaksi saham, struktur industri, dan lain-lain. Faktor-faktor lain tersebut terdapat pada rumus Capital Asset Pricing Model (CAPM) sebagai error (e).

\section{Seleksi Saham yang Optimal Berdasarkan Cut Off Point (COP)}

Metode Cut Off Point merupakan metode untuk mencari derajat kebutuhan. Pada optimalisasi saham, metode Cut Off Point digunakan sebagai pembatas antara saham yang tidak optimal dengan saham yang masuk pada Saham yang dipilih. Sebelum menggunakan Cut Off Point, data dari 41 saham perusahaan diurutkan berdasarkan tingkat pengembalian yang diharapkan terbesar ke yang terkecil yang dihitung dengan menggunakan Capital Asset Pricing Model (CAPM).

Nilai tingkat pengembalian tertinggi yaitu milik perusahaan Gudang Garam sebesar 0,00817523. Sementera itu, nilai tingkat pengebalian terendah yaitu milik perusahaan Excelcomindo Pratama sebesar 0,00231726. Untuk melakukan Cut Off Point digunakan persamaan

Natural cut off point $=\frac{\operatorname{maks}\left(E\left(R_{i}\right)\right)+\min \left(E\left(R_{i}\right)\right)}{2}$

Dimana :

$\operatorname{maks}\left(E\left(R_{i}\right)\right)=$ nilai rata-rata maksimum

$\min \left(E\left(R_{i}\right)\right)=$ nilai rata-rata minimum

dan diperoleh nilai Cut Off Point dari tingkat pengembalian yang diharapkan sebesar 0,005246, sehingga didapat 18 saham perusahaan yang masuk kedalam saham yang optimal karena nilai tingkat pengembalian yang diharapkan berada diatas nilai Cut Off Point.

Tabel 6. Risiko Sistematis ( $\beta$ ) dan Tingkat Pengembalian yang Diharapkan dari 18 Perusahaan yang Masuk pada Saham Optimal.

\begin{tabular}{lrr}
\hline \multicolumn{1}{c}{ Nama Perusahaan } & \multicolumn{1}{c}{$\boldsymbol{E}\left(\boldsymbol{R}_{\text {it }}\right)$} & \multicolumn{1}{c}{ B } \\
\hline Gudang Garam Tbk & 0.00817523 & 0.55531 \\
Astra Argo Lesatari & 0.00781118 & 0.647809 \\
Tbk & & \\
Lippo Karawaci Tbk & 0.00753358 & 1.337836 \\
Global Mediacom Tbk & 0.00750728 & 1.080889 \\
Adhi Karya (Persero) & 0.007372 & 1.713233 \\
Tbk & & \\
\hline
\end{tabular}




\begin{tabular}{lrr}
\hline $\begin{array}{l}\text { Indofood CBP Sukses } \\
\text { Makmur Tbk }\end{array}$ & 0.007305 & 1.711892 \\
$\begin{array}{l}\text { Semen Indonesia } \\
\text { (Persero) Tbk. }\end{array}$ & 0.00693133 & 1.529506 \\
$\begin{array}{l}\text { Charoen Pokphand } \\
\text { Indonesia Tbk }\end{array}$ & 0.006335 & 1.584885 \\
$\begin{array}{l}\text { Media Nusantara Citra } \\
\text { Tbk }\end{array}$ & 0.0061953 & 1.442297 \\
$\begin{array}{l}\text { Pembangunan } \\
\text { Perumahan (persero) }\end{array}$ & 0.00582172 & 1.981403 \\
Tbk & & \\
Pakuwon Jati Tbk. & 0.00575046 & 1.446245 \\
United Tractor Tbk & 0.00573344 & 1.330237 \\
Kalbe Farma Tbk & 0.00561178 & 0.713627 \\
Astra Internasional Tbk & 0.00565584 & 1.284983 \\
Matahari Putra Prima & 0.0054426 & 1.447398 \\
Tbk & & \\
Ciputra Development & 0.00538403 & 2.008539 \\
Tbk & & \\
Wijaya Karya (persero) & 0.00530983 & 1.739037 \\
Tbk & 0.005305 & 1.095369 \\
\hline BCA (Persero) Tbk & & \\
\hline Sumber:
\end{tabular}

Sumber : data diolah

Berdasarkan Tabel 6. rata-rata tingkat keuntungan pengembalian yang diharapkan dari 18 saham perusahaan-perusahaan yang tercatat pada saham optimal adalah sebesar 0,0064 atau $0,64 \%$. Tingkat keuntungan pengembalian yang diharapkan saham perusahaan Gudang Garam Tbk (GGRM) memiliki tingkat keuntungan pengembalian yang diharapkan tertinggi dibandingkan 18 saham perusahaan lainnya, yaitu sebesar 0,0082 atau $0,82 \%$ perbulan. Sementara itu, Return Ekspektasi saham perusahaan Bank Central Asia Tbk (BBCA) memiliki tingkat Return Ekspektasi terendah yaitu sebesar 0,0053 atau $0,53 \%$.

\section{Kesimpulan}

Berdasarkan hasil pembahasan, dapat diambil kesimpulan sebagai berikut:

1. Untuk mendapatkan nilai tingkat pengembalian yang diharapkan dan risiko sitematis ( $\beta$ ) saham masing-masing perusahaan dengan menggunakan Capital Asset Pricing Model (CAPM), diperoleh hasil :

a. Terdapat 30 saham perusahaan yang memiliki $\beta>1$. Ini berarti $73,17 \%$ dari 41 saham perusahaan yang diteliti menunjukkan harga saham yang lebih mudah berubah dibandingkan dengan Indeks pasar. Sementara itu, 11 saham perusahaan yang memiliki $\beta<1$. Ini berarti $26,83 \%$ saham perusahaan mempunyai risiko lebih kecil daripada risiko pasar.

b. Semua saham perusahaan mempunyai pengembalian yang diharapkan atau expected return yang bernilai positif. Ini berarti, 41 saham perusahaan tersebut layak untuk dijadikan kandidat portofolio saham yang optimal.

2. Dari 41 perusahaan dengan menggunakan metode Cut Off Point (COP), diperoleh 18 saham yang tercatat pada saham yang optimal dengan nilai rata-rata expected return sebesar 0,0064 atau $0,64 \%$ dan risiko sebesar 1,297. Rata-rata nilai tingkat pengembalian yang diharapkan tersebut berada diatas rata-rata return bebas risiko yang sebesar 0,0056 atau $0,56 \%$ dan diatas rata-rata return pasar yang sebesar 0,0054 atau 0,54\%, sehingga berinvestasi pada saham lebih menguntungkan dibandingkan investasi bebas risiko.

\section{DAFTAR PUSTAKA}

Ahmad, K. (2004). Dasar-dasar manajemen Investasi dan Portofolio. Asdi Mahasatya. Jakarta.

Darmadji, Tjiptono, dan Fakhruddin, Hendy M. (2006). Pasar Modal di Indonesia: Pendekatan Tanya Jawab. Salemba Empat. Jakarta.

Fabozzi, F dkk. (2010). Pasar dan Lembaga Keuangan. Jakarta: Salemba Empat.

Halim. (2003). Analisis Investasi. Erlangga. Jakarta.

Hartono, J. (2013). Teori Portofolio dan Analisis Investasi. BPFE. Yogyakarta. 
Hasan, Md. Zobaer., dkk. (2012). international conference on accounting and finance. Vol.2 hal 1-8.

http://ekbis.sindonews.com/read/809409/32/p erlambatan-ekonomi-buat-ihsg-tergerus$\underline{1385273235}$

http://nasional.sindonews.com/read/969180 Relationship berween Risk and Expected Returns: Evidence from the Dhaka Stock Exchange. 2nd annual /18/menebakarah-bi-rate-1424920368

http://www.bi.go.id/en/moneter/bi-rate/data/ Default.aspx

http://www.britama.com/index.php/2015/01/ daftar-saham-indeks-lq-45-periode februari-juli-2015/

Husnan, S. 1998. Dasar-dasar Teori Portofolio dan Analisis Sekuritas. Edisi Ketiga. BPFE. Yogyakarta

Masrukan, E. 2013. Optimalisasi Nilai Risiko Portofolio Saham Berdasarkan MeanVar. Skripsi Matematika, Jurusan Matematika, Universitas Brawijaya.

Rodoni, A dkk. (2002). Analisis Investasi dan Teori Portofolio. Raja Grafindo Persada. Jakarta.

Sugiyono. (2008). Metode Penelitian Bisnis. Pusat Bahasa Depdiknas. Bandung.

Sumarsono, Sonny.(2004). Metode Riset Sumber Daya Manusia. Graha Ilmu. Yogyakarta.

Sunariyah. (2004). Pengantar Pengetahuan Pasar Modal. UPP STIM YPKN. Yogyakarta.

Tam, M.C.Y. (1996). An Application of The AHP In Vendor Selection of A Talecomunication System. University of Hong Kong. Hong Kong.
Wijayanti, P. 2013. Pemilihan Saham dan Pembentukan Portofolio Optimal dengan Menggunakan Data Envelopment Analysis (DEA) dan Model Indeks Tunggal pada Bursa Efek Indonesia. Skripsi Matematika, Jurusan Matematika, Universitas Brawijaya.

Yayan, M. 2015. Optimalisasi Portofolio Saham Menggunakan DEA dan MeanVar. Skripsi Matematika, Jurusan Matematika, Universitas Brawijaya. 